\title{
PENGARUH DOSIS PUPUK NPK DAN JENIS PUPUK PELENGKAP TERHADAP PERTUMBUHAN DAN PRODUKSI CABAI (Capsicum annuum L.)
}

\author{
Effect of NPK Fertilizer Dosage and Complementary Fertilizer Types on Growth and \\ Yield of Chili Pepper (Capsicum annuum L.)
}

\author{
Kus Hendarto $^{1 *}$, Yohannes C. Ginting ${ }^{1}$, Agus Karyanto ${ }^{1}$, Virginia Chintya Amanda ${ }^{2}$ \\ ${ }^{1}$ Jurusan Agroteknologi, Fakultas Pertanian, Universitas Lampung \\ ${ }^{2}$ Jurusan Agronomi dan Hortikultura, Fakultas Pertanian, Universitas Lampung \\ Jl. Sumantri Brojonegoro No 1 Gedung Meneng, Bandar Lampung 35145 \\ *E-mail korespondensi: kus.hendarto@fp.unila.ac.id
}

\begin{abstract}
ABSTRAK
Penelitian ini bertujuan untuk mengetahui pengaruh dosis NPK dan jenis pupuk pelengkap terhadap pertumbuhan dan produksi cabai. Penelitian ini dilakukan di Desa Sukabanjar, Kecamatan Gedong Tataan, Kabupaten Pesawaran, Lampung pada Juli - Desember 2020. Rancangan percobaan yang digunakan adalah Rancangan Acak Kelompok (RAK) dengan dua faktor yaitu dosis pupuk NPK dan jenis pupuk pelengkap $(4 \times 2)$ dan 3 ulangan. Setiap petak terdiri atas 8 tanaman sehingga terdapat 192 tanaman. Faktor pertama adalah dosis pupuk NPK Mutiara (16:16:16) (N) yaitu 0, 10, 20, dan 30 g/tanaman. Faktor kedua adalah jenis pupuk pelengkap yaitu Plant Catalyst dan Gandasil D. Homogenitas ragam diuji dengan uji Bartlett, sedangkan uji additivitas data diuji dengan uji Tukey. Jika asumsi terpenuhi data dianalisis dengan sidik ragam. Perbedaan nilai tengah diuji dengan BNT pada taraf 5\%. Pemberian dosis pupuk NPK dipengaruhi oleh jenis pupuk pelengkap. Sedangkan jenis pupuk pelengkap nyata dalam meningkatkan semua variabel pengamatan kecuali bobot buah rusak per tanaman. Hasil penelitian menunjukkan bahwa Interaksi dosis pupuk NPK dan Plant Catalyst berpengaruh terhadap pertumbuhan dan hasil cabai merah. Interaksi dosis pupuk NPK $20 \mathrm{~g} /$ tanaman dan pupuk Gandasil D menghasilkan tinggi tanaman tertinggi yaitu sebesar 95,58 cm. Interaksi dosis NPK $20 \mathrm{~g} /$ tanaman dan pupuk Plant Catalyst memberikan hasil tertinggi yaitu 753,17 g/tanaman atau 15,06 ton/ha pada populasi 20.000 tanaman.
\end{abstract}

Kata kunci: Cabai, hasil, NPK, pertumbuhan, pupuk pelengkap

\begin{abstract}
This study aims to determine the effect of NPK dosage, types of complementary fertilizers and their interactions on the growth and production of chilies pepper. This research was conducted in Sukabanjar Village, Gedong Tataan, Pesawaran Regency from July-December 2020. The experimental design used in this study was a two-factor randomized block design (RBD), namely the dose of NPK fertilizer and the type of complementary fertilizer $(4 \times 2)$ with 3 replications. Each plot consisted of 8 plants so that there were 192 plants. The first factor was NPK Mutiara fertilizer dose (16:16:16)(N) with $N_{0}: 0 \mathrm{~g} /$ plant, $N_{1}: 10 \mathrm{~g} /$ plant, $N_{2}: 20 \mathrm{~g} /$ plant and $N_{3}: 30 \mathrm{~g} /$ plant. The second factor is the type of complementary fertilizer $(P)$ with $P_{1}$ Plant Catalyst and $P_{2}$ Gandasil D. Homogeneity of variance was tested by Bartlett test, additivity was tested by Tukey test. Then it was continued with analysist of variance and with the Least Significant Difference test (LSD) at the 5\% level. Treatment of NPK fertilizer dosage significantly increases growth and yield. The interaction between the NPK dosage of $20 \mathrm{~g} /$ plant and type of complementary fertilizers gave highest plant height $(95.58 \mathrm{~cm})$. The best combination was NPK dosage of $20 \mathrm{~g}$ /plant and Plant Catalyst fertilizer that gave highest yield $(753,17$ $\mathrm{g} /$ plant equivalent 15.06 ton/ha at population 20,000 plant/ha.
\end{abstract}

Keywords : Chili pepper, complimentary fertilizer, growth, NPK, yield 


\section{PENDAHULUAN}

Cabai merah (Capsicum annuum L.) merupakan salah satu komoditas penting dalam kehidupan masyarakat Indonesia. Cabai merah diminati karena dapat dipastikan selalu tersedia diberbagai jamuan di Indonesia. Cabai mengandung berbagai senyawa diantaranya mengandung vitamin $\mathrm{C}$ yang baik bagi tubuh manusia. Selain itu, cabai mampu menangkal radikal bebas di dalam tubuh manusia karena mengandung antioksidan. Cabai juga mengandung capsaicin yang merupakan senyawa penyebab rasa pedas pada cabai, cita rasa pedas yang ditimbulkan menjadi ciri khas bumbu pada berbagai masakan di Indonesia, hal ini yang menyebabkan cabai merah menjadi salah satu sayuran buah yang bernilai ekonomis tinggi (Agriflo, 2012).

Berdasarkan data Kementerian Pertanian Republik Indonesia (2019), produktivitas cabai besar di Provinsi Lampung selama periode 2015 - 2019 cenderung menurun yang hanya mencapai 6,23 ton/ha pada tahun 2019. Produktivitas tersebut masih di bawah produktivitas cabai nasional yang dapat mencapai 8,69 ton/ha dan potensi produktivitas cabai yang dapat mencapai $15-20$ ton/ha. Salah satu penyebab rendahnya produktivitas cabai yaitu pengelolaan tanah yang tidak tepat sehingga kesuburan tanah terus menurun, terutama pada jenis tanah masam ber-pH rendah seperti tanah ultisol yang memerlukan pengelolaan yang tepat (Novizan, 2007).

Budidaya tanaman cabai secara umum menggunakan input yang tinggi terutama penggunaan pupuk urea, ZA, SP-36 dan $\mathrm{KCl}$ secara terus menerus setiap musim tanam yang dapat menurunkan kualitas lahan sehingga kurang efisien dan tidak dapat meningkatkan hasil (Purnomo, 2013). Penggunaan pupuk NPK majemuk lebih efisien ditinjau dari segi aplikasi dibandingkan dengan pupuk tunggal karena unsur $\mathrm{N}, \mathrm{P}$ dan $\mathrm{K}$ terdapat dalam satu jenis pupuk dan dapat mendorong petani untuk menggunakan pupuk secara lengkap. Penggunaan pupuk NPK majemuk hendaknya mengacu pada status hara dalam tanah dan kebutuhan hara tanaman. Namun pupuk NPK majemuk yang ada saat ini mempunyai kadar $\mathrm{N}, \mathrm{P}$ dan $\mathrm{K}$ yang kurang sesuai sehingga sulit menetapkan dosis yang tepat untuk tanah yang mengandung $\mathrm{P}$ dan $\mathrm{K}$ tinggi (Hartatik dan Widowati, 2015). Oleh karena itu diperlukan penambahan jenis pupuk yang dapat melengkapi kebutuhan unsur hara sesuai fase pertumbuhan tanaman sehingga diperoleh dosis NPK majemuk yang sesuai untuk meningkatkan pertumbuhan dan produksi tanaman. Dalam penelitian ini pemupukan dilakukan dengan menggunakan pupuk NPK Mutiara 16-16-16 dan pupuk pelengkap yaitu Plant Catalyst dan Gandasil D.

Pupuk majemuk (NPK) merupakan salah satu pupuk anorganik yang dapat digunakan dalam meningkatkan ketersediaan unsur hara makro $(\mathrm{N}, \mathrm{P}$, dan $\mathrm{K})$, menggantikan pupuk tunggal seperti Urea, SP-36, dan $\mathrm{KCl}$ yang sulit diperoleh di pasaran dan sangat mahal. Keuntungan menggunakan pupuk majemuk (NPK) adalah dapat dipergunakan dengan memperhitungkan kandungan zat hara sama dengan pupuk tunggal, apabila tidak ada pupuk tunggal dapat diatasi dengan pupuk majemuk, penggunaan pupuk majemuk sangat sederhana, dalam pengangkutan dan penyimpanan pupuk ini menghemat waktu, ruangan, dan biaya (Kaya, 2013).

Plant Catalyst adalah salah satu pupuk pelengkap yang berfungsi sebagai katalisator dalam mengoptimalkan penyerapan unsur hara makro seperti $(\mathrm{N}, \mathrm{P}$, $\mathrm{K}, \mathrm{S}, \mathrm{Ca}, \mathrm{Mg}$ ) di dalam tanah yang berasal dari pemupukan (Urea, TSP, KCl, ZA) oleh tanaman. Pupuk Plant Catalyst mengandung unsur hara lengkap yang dibutuhkan untuk pertumbuhan tanaman meliputi unsur hara makro dan unsur hara mikro. Unsur hara makro yang terkandung adalah (N, P, K, Ca, Mg, S), sedangkan unsur hara mikro yang terkandung adalah ( $\mathrm{Fe}, \mathrm{Cl}, \mathrm{Mn}, \mathrm{Cu}, \mathrm{Zn}, \mathrm{B}$ dan Mo). Pemupukan 
tanaman dengan Urea, TSP, KCl, NPK, dan ZA seringkali kurang efektif karena tidak semua unsur hara dapat diserap oleh tanaman dikarenakan beberapa faktor seperti pencucian, penguapan dan keterbatasan kemampuan tanaman untuk menyerap unsur hara tersebut, sehingga pupuk Plant Catalyst digunakan untuk melengkapi kebutuhan unsur hara tanaman yang tidak didapatkan dari pemupukan dengan pupuk tersebut (PT Centranusa Insan Cemerlang, 2014).

Pupuk gandasil D yaitu pupuk daun yang berfungsi sebagai penambah unsur hara pada tanaman. Unsur hara yang terkandung dalam Gandasil D yaitu Nitrogen (N) 20\%, Fosfat $\left(\mathrm{P}_{2} \mathrm{O}_{5}\right) 15 \%$, Kalium $\left(\mathrm{K}_{2} \mathrm{O}\right) 15 \%$, Magnesium $\left(\mathrm{MgSO}_{4}\right) \quad 1 \%$ dan dilengkapi unsur-unsur lainnya seperti Mangan (Mn), Boron (B), Tembaga (Cu), Seng ( $\mathrm{Zn})$ dan vitamin seperti Aneurine, Lactoflavine, serta Nicotinic acid amide (Qibtyah, 2015).

Penelitian ini bertujuan untuk mengetahui pengaruh pemberian dosis pupuk NPK, dan jenis pupuk pelengkap serta interaksinya terhadap pertumbuhan dan produksi cabai merah.

\section{METODE PENELITIAN}

Penelitian ini dilaksanakan di Desa Sukabanjar, Kecamatan Gedong Tataan, Kabupaten Pesawaran, Provinsi Lampung yang terletak pada posisi lintang $5^{\circ} 21^{\prime} 13$ ', LS dan $105^{\circ} 10^{\prime} 30^{\prime}$ ' LU, dari Juli sampai Desember 2020. Alat yang digunakan dalam penelitian ini adalah cangkul, meteran, jangka sorong, sprayer, gembor, ember, botol plastik, plastik transparan ukuran $3 \times 4$ $\mathrm{cm}$, mulsa plastik perak, patok, bambu, tali rafia, kamera, alat tulis, timbangan. Bahan yang digunakan dalam penelitian ini adalah benih cabai varietas Indrapura Paten, pupuk kandang kotoran kambing, Dolomit, NPK mutiara, dan pupuk pelengkap dengan merek dagang Plant Catalyst dan Gandasil D. Komposisi unsur hara Plant Catalyst disajikan pada Tabel 1 .
Tabel 1. Komposisi unsur pupuk Plant Catalyst

\begin{tabular}{llll}
\hline $\begin{array}{l}\text { Unsur } \\
\text { Hara }\end{array}$ & Kandungan & $\begin{array}{l}\text { Unsur } \\
\text { Hara }\end{array}$ & Kandungan \\
\hline $\mathrm{N}$ & $0,23 \%$ & $\mathrm{Mn}$ & $2,37 \mathrm{ppm}$ \\
$\mathrm{P}$ & $12,70 \%$ & $\mathrm{Cu}$ & $<0,03 \mathrm{ppm}$ \\
$\mathrm{K}$ & $0,88 \%$ & $\mathrm{Co}$ & $9,59 \mathrm{ppm}$ \\
$\mathrm{Ca}$ & $<0,05 \mathrm{ppm}$ & $\mathrm{Zn}$ & $11,15 \mathrm{ppm}$ \\
$\mathrm{Mg}$ & $25,92 \mathrm{ppm}$ & $\mathrm{Mo}$ & $35,37 \mathrm{ppm}$ \\
$\mathrm{S}$ & $0,02 \%$ & $\mathrm{Al}$ & $<0,4 \mathrm{ppm}$ \\
$\mathrm{C}$ & $6,47 \%$ & $\mathrm{~B}$ & $0,25 \%$ \\
$\mathrm{Fe}$ & $36,45 \mathrm{ppm}$ & $\mathrm{Na}$ & $27,42 \%$ \\
$\mathrm{Cl}$ & $0,11 \%$ & & \\
\hline
\end{tabular}

Penelitian ini menggunakan Rancangan Acak Kelompok (RAK) yang disusun secara faktorial $(4 \times 2)$ dengan tiga ulangan. Faktor pertama adalah dosis pupuk NPK Mutiara (16: $16: 16)(\mathrm{N})$ dengan dosis $0,10,20$ dan $30 \mathrm{~g} / \operatorname{tanaman}$ atau $0,200,400$ dan $600 \mathrm{~kg} / \mathrm{ha}$. Faktor kedua adalah jenis pupuk pelengkap Plant Catalyst dan Gandasil D dengan konsentrasi masing masing $2 \mathrm{~g} / \mathrm{l}$. Terdapat 8 kombinasi perlakuan dan masing - masing diulang sebanyak 3 kali sehingga didapatkan 24 satuan percobaan. Masing - masing satuan percobaan terdiri dari 8 tanaman sehingga terdapat 192 tanaman. Homogenitas ragam diuji dengan uji Bartlett, sedangkan uji additivitas data diuji dengan uji Tukey. Jika asumsi terpenuhi data dianalisis dengan sidik ragam. Perbedaan nilai tengah diuji dengan BNT pada taraf 5\%.

Data tinggi tanaman yang dianalisis merupakan data akhir pengamatan yaitu pada tanaman berumur 19 minggu setelah tanam (mst) sedangkan data jumlah buah per tanaman, bobot buah per tanaman, bobot buah per $\mathrm{m}^{2}$ dan bobot buah rusak per tanaman dilakukan analisis menggunakan data jumlah panen pertama hingga terakhir mulai dari minggu ke 12 hingga minggu ke 19.

Pengolahan tanah dilakukan sebanyak dua kali. Pengolahan tanah pertama bertujuan untuk mematikan gulma dan membalik tanah, sedangkan olah tanah kedua bertujuan untuk menghaluskan dan menggemburkan tanah. Kemudian dibuat 
guludan dengan ukuran $1 \mathrm{~m} \times 25 \mathrm{~m}$ dan dilakukan pemberian pupuk dasar yaitu pupuk kandang kambing sebanyak 20 - 30 ton/ha dan dolomit sebanyak 4 ton/ha. Selanjutnya guludan dipasang mulsa dan dilubangi dengan jarak tanam 0,6 $\mathrm{m} \times 0,8 \mathrm{~m}$.

Benih yang digunakan yaitu benih cabai varietas Indrapura paten. Benih disemai pada plastik-plastik kecil yang berisi media tanam berupa top soil yang telah diayak sebelumnya. Bibit cabai merah dipindahkan ke lahan terbuka setelah berumur 25 - 30 hari setelah semai (hss) atau telah memiliki $4-6$ helai daun yang telah terbuka. Dalam satu satuan percobaan diambil sebanyak 2 sampel tanaman secara acak yang kemudian diberi label. Perlakuan aplikasi pupuk NPK dilakukan sebanyak 3 kali aplikasi yaitu pada 2, 4 dan 8 minggu setelah tanam (mst) dengan pembagian 50, 25 dan $25 \%$. NPK diberikan dengan cara menaburkan pupuk di sekitar tanaman kemudian ditutup dengan tanah. Kemudian aplikasi pupuk pelengkap dilakukan setiap minggu hingga minggu ke 8 .

Pupuk pelengkap diaplikasikan dengan cara disemprot di bagian daun dengan konsentrasi $2 \mathrm{~g} / \mathrm{l}$, masing - masing tanaman disemprot larutan pupuk pelengkap sebanyak $100 \mathrm{ml} /$ tanaman. Pemeliharaan tanaman meliputi penyiangan gulma, penyiraman, pengajiran, pewiwilan dan pengendalian OPT. Penyiangan gulma dilakukan secara manual jika terdapat gulma yang tumbuh pada lubang tanam, dengan cara mencabut langsung dengan tangan pada saat setiap gulma muncul. Penyiangan rutin dilakukan minimal satu minggu sekali.

Penyiraman dilakukan dua kali sehari dengan menggunakan gembor. Gembor yang digunakan berukuran 10 liter yang digunakan untuk menyiram 4 tanaman. Pengajiran dilakukan dengan menambahkan ajir bambu pada setiap tanaman untuk menopang tanaman agar kuat. Ukuran lebar bambu yang digunakan $3-4 \mathrm{~cm}$ dengan tinggi $120 \mathrm{~cm}$. Tanaman diikatkan ke bambu dengan menggunakan tali rafia dengan teknik mengikat membentuk angka delapan.

Pewiwilan dilakukan dengan membuang tunas air yang tumbuh di ketiak daun. Pewiwilan dilakukan setiap tunas air tumbuh pada masa vegetatif maupun generatif. Pengendalian OPT dapat dilakukan secara mekanik dan kimiawi sesuai dengan jenis OPT yang menyerang. Hama siput pada bibit dikendalikan dengan Toxiput 5GR dengan menaburkan di dekat lubang tanam, lalat buah dikendalikan dengan menggunakan perangkap (Yellow trap) yang dipasang di luar area guludan, ulat buah cabai dikendalikan dengan penyemprotan menggunakan insektisida Asmec 36 EC dengan konsentrasi 0,5 ml/1 dan penyakit antraknosa dikendalikan dengan fungisida Dithane M-45 dengan konsentrasi $3 \mathrm{~g} / \mathrm{l}$.

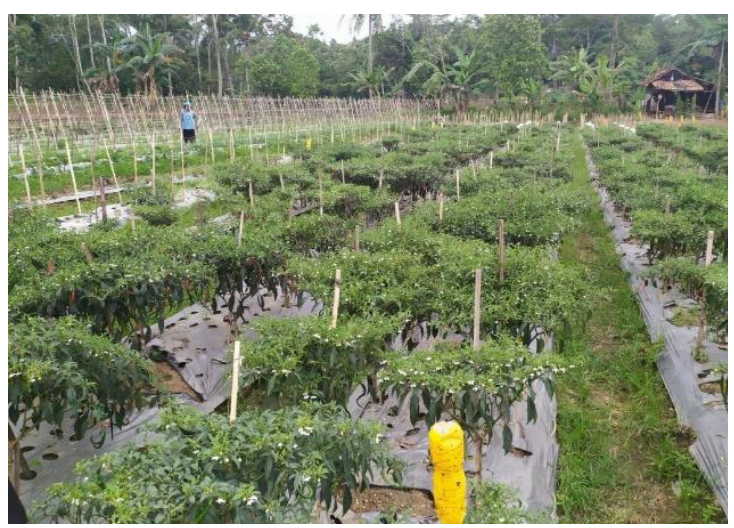

Gambar 1. Plot percobaan

Pemanenan dilakukan setiap satu minggu sekali. Variabel yang diamati yaitu tinggi tanaman, jumlah buah per tanaman, bobot buah per tanaman, bobot buah per $\mathrm{m}^{2}$ dan bobot buah rusak per tanaman.

\section{HASIL DAN PEMBAHASAN}

Berdasarkan hasil analisis ragam, pengaruh dosis pupuk NPK, jenis pupuk pelengkap dan interaksinya berpengaruh nyata pada beberapa variabel pengamatan. Hasil rekapitulasi tersebut disajikan pada Tabel 2. Perlakuan dosis pupuk NPK berpengaruh nyata pada semua variabel 
pengamatan. Jenis pupuk pelengkap dan interaksi kedua perlakuan berpengaruh nyata pada tinggi tanaman 19 minggu setelah tanam (mst), jumlah buah per tanaman, bobot buah per tanaman dan bobot buah per $\mathrm{m}^{2}$.

Tabel 2. Rekapitulasi pengaruh dosis pupuk NPK dan jenis pupuk pelengkap pada beberapa variabel pengamatan

\begin{tabular}{lccc}
\hline \multirow{2}{*}{$\begin{array}{c}\text { Variabel } \\
\text { Pengamatan }\end{array}$} & $\begin{array}{c}\text { Perlakuan } \\
\text { Nosis }\end{array}$ & $\begin{array}{c}\text { Pupuk } \\
\text { Pelengkap }\end{array}$ & Interaksi \\
\hline $\begin{array}{l}\text { Tinggi } \\
\text { tanaman }\end{array}$ & $* *$ & $*$ & $*$ \\
$\begin{array}{l}\text { Jumlah Buah } \\
\text { per Tanaman }\end{array}$ & $* *$ & $* *$ & $*$ \\
$\begin{array}{l}\text { Bobot Buah } \\
\text { per tanaman }\end{array}$ & $* *$ & $* *$ & $* *$ \\
$\begin{array}{l}\text { Bobot Buah } \\
\text { per m }{ }^{2}\end{array}$ & $* *$ & $* *$ & $*$ \\
$\begin{array}{l}\text { Bobot Buah } \\
\text { rusak per } \\
\text { tanaman }(\mathrm{g})\end{array}$ & $* *$ & tn & tn \\
\hline
\end{tabular}

Keterangan: $\mathrm{tn}=$ tidak nyata, $*=$ berbeda pada $\alpha 5 \%, * *=$ berbeda pada $\alpha 1 \%$

\section{Tinggi Tanaman}

Hasil uji lanjut BNT 5\% (Tabel 3). menunjukkan bahwa pada perlakuan pupuk Plant Catalyst $\left(\mathrm{P}_{1}\right)$, aplikasi dosis pupuk NPK 20 g/tanaman $\left(\mathrm{N}_{2}\right)$ menghasilkan tinggi tanaman yang tertinggi dibandingkan dengan perlakuan dosis NPK lainnya. Pemberian dosis NPK $20 \mathrm{~g} / \operatorname{tanaman}\left(\mathrm{N}_{2}\right)$ berbeda nyata dengan perlakuan dosis NPK $0 \mathrm{~g} /$ tanaman dan $10 \mathrm{~g} / \mathrm{tanaman}$, namun tidak berbeda nyata dengan pemberian dosis NPK 30 g/tanaman $\left(\mathrm{N}_{3}\right)$. Pada aplikasi pupuk Gandasil D $\left(\mathrm{P}_{2}\right)$, perlakuan dosis pupuk NPK $20 \mathrm{~g} /$ tanaman $\left(\mathrm{N}_{2}\right)$ menghasilkan tinggi tanaman tertinggi dibandingkan dengan perlakuan dosis NPK lainnya. Dosis pupuk NPK $30 \mathrm{~g} /$ tanaman, $10 \mathrm{~g} /$ tanaman dan 0 $\mathrm{g} /$ tanaman menghasilkan tinggi tanaman yang tidak berbeda nyata.

Pada perlakuan dosis NPK 0 $\mathrm{g} / \operatorname{tanaman}\left(\mathrm{N}_{0}\right), 10 \mathrm{~g} / \operatorname{tanaman}\left(\mathrm{N}_{1}\right)$ dan 30 g/tanaman $\left(\mathrm{N}_{3}\right)$ menghasilkan tinggi tanaman yang tidak berbeda nyata baik dengan aplikasi pupuk Plant Catalyst $\left(\mathrm{P}_{1}\right)$ maupun pupuk Gandasil D $\left(\mathrm{P}_{2}\right)$, tetapi perlakuan dosis NPK $20 \mathrm{~g} /$ tanaman aplikasi pupuk Gandasil D menghasilkan tinggi tanaman yang lebih tinggi yaitu sebesar 95,58 $\mathrm{cm}$ dibandingkan dengan perlakuan pupuk Plant Catalyst yang menghasilkan tinggi tanaman sebesar $88,33 \mathrm{~cm}$ dengan selisih 7,25 $\mathrm{cm}$ atau sebesar $8,21 \%$.

Tabel 3. Pengaruh pemberian dosis pupuk NPK dan jenis pupuk pelengkap pada tinggi tanaman 19 mst $(\mathrm{cm})$

\begin{tabular}{ccc}
\hline \multirow{2}{*}{$\begin{array}{c}\text { Dosis NPK } \\
(\mathrm{g} / \text { tanaman })\end{array}$} & \multicolumn{2}{c}{ Jenis Pupuk Pelengkap } \\
\cline { 2 - 3 } & $\begin{array}{c}\text { Plant } \\
\text { Catalyst }\left(\mathrm{P}_{1}\right)\end{array}$ & $\begin{array}{c}\text { Gandasil D } \\
\left(\mathrm{P}_{2}\right)\end{array}$ \\
\hline \multirow{2}{*}{$0\left(\mathrm{~N}_{0}\right)$} & $76,00 \mathrm{~A}$ & $79,50 \mathrm{~A}$ \\
& $\mathrm{c}$ & $\mathrm{b}$ \\
$10\left(\mathrm{~N}_{1}\right)$ & $81,17 \mathrm{~A}$ & $82,83 \mathrm{~A}$ \\
& $\mathrm{~b}$ & $\mathrm{~b}$ \\
$20\left(\mathrm{~N}_{2}\right)$ & $88,33 \mathrm{~B}$ & $95,58 \mathrm{~A}$ \\
& $\mathrm{a}$ & $\mathrm{a}$ \\
$30\left(\mathrm{~N}_{3}\right)$ & $85,50 \mathrm{~A}$ & $83,00 \mathrm{~A}$ \\
\hline BNT 5\% & $\mathrm{a}$ & $\mathrm{b}$ \\
\hline \multicolumn{3}{c}{4,29} \\
\hline
\end{tabular}

Keterangan: Angka sebaris yang diikuti huruf besar yang sama dan angka sekolom yang diikuti huruf kecil yang sama menunjukkan tidak berbeda nyata pada taraf $5 \%$.

\section{Jumlah Buah per Tanaman}

Hasil uji lanjut BNT 5\% (Tabel 4). menunjukkan bahwa pada perlakuan pupuk Plant Catalyst, aplikasi dosis pupuk NPK 20 g/tanaman menghasilkan jumlah buah lebih banyak dibandingkan dengan aplikasi dosis pupuk NPK $30 \mathrm{~g} /$ tanaman, $10 \mathrm{~g} /$ tanaman dan $0 \mathrm{~g} /$ tanaman. Tetapi aplikasi dosis pupuk NPK $10 \mathrm{~g} /$ tanaman dan $30 \mathrm{~g} / \mathrm{tanaman}$ menghasilkan jumlah buah yang tidak berbeda nyata. Pada perlakuan pupuk Gandasil D, aplikasi dosis pupuk NPK pada perlakuan pupuk tidak berbeda nyata terhadap jumlah buah per tanaman.

Perlakuan dosis pupuk NPK 0 $\mathrm{g} /$ tanaman, $10 \mathrm{~g} /$ tanaman dan $30 \mathrm{~g} /$ tanaman tidak berbeda nyata terhadap jumlah buah per tanaman baik dengan aplikasi pupuk 
pelengkap Plant Catalyst maupun pupuk Gandasil D. Namun, pada perlakuan dosis pupuk NPK $20 \mathrm{~g} /$ tanaman, aplikasi pupuk Plant Catalyst menghasilkan jumlah buah yang lebih banyak yaitu sebesar 184,33 buah dibandingkan dengan aplikasi pupuk Gandasil D yang hanya sebesar 94,5 buah dengan selisih 89,83 buah atau sebesar $95,1 \%$. Diagram batang pengaruh pemberian dosis pupuk NPK dan jenis pupuk pelengkap terhadap jumlah buah per tanaman dapat dilihat pada Gambar 2.

Tabel 4. Pengaruh pemberian dosis pupuk NPK dan jenis pupuk pelengkap pada jumlah buah per tanaman

\begin{tabular}{ccc}
\hline $\begin{array}{c}\text { Dosis NPK } \\
(\mathrm{g} / \text { tanaman })\end{array}$ & $\begin{array}{c}\text { Jenis Pupuk Pelengkap } \\
\text { Plant } \\
\text { Catalyst }\left(\mathrm{P}_{1}\right)\end{array}$ & $\begin{array}{c}\text { Gandasil D } \\
\left(\mathrm{P}_{2}\right)\end{array}$ \\
\hline $0\left(\mathrm{~N}_{0}\right)$ & $54,17 \mathrm{~A}$ & $68,33 \mathrm{~A}$ \\
& $\mathrm{c}$ & $\mathrm{b}$ \\
$10\left(\mathrm{~N}_{1}\right)$ & $109,17 \mathrm{~A}$ & $76,17 \mathrm{~A}$ \\
& $\mathrm{~b}$ & $\mathrm{a}$ \\
$20\left(\mathrm{~N}_{2}\right)$ & $184,33 \mathrm{~A}$ & $94,50 \mathrm{~B}$ \\
& $\mathrm{a}$ & $\mathrm{a}$ \\
$30\left(\mathrm{~N}_{3}\right)$ & $111,67 \mathrm{~A}$ & $77,00 \mathrm{~A}$ \\
& $\mathrm{~b}$ & $\mathrm{a}$ \\
\hline BNT 5\% & \multicolumn{3}{c}{39,18} \\
\hline
\end{tabular}

Keterangan: Angka sebaris yang diikuti huruf besar yang sama dan angka sekolom yang diikuti huruf kecil yang sama menunjukkan tidak berbeda nyata pada taraf $5 \%$.



Gambar 2. Pengaruh pemberian dosis pupuk NPK dan jenis pupuk pelengkap pada jumlah buah per tanaman

\section{Bobot Buah per Tanaman}

Selain jumlah buah per tanaman, bobot buah per tanaman merupakan karakter agronomi yang penting pada tanaman cabai (Syukur et al., 2010). Hasil uji lanjut BNT 5\% (Tabel 5). Menunjukkan bahwa pada perlakuan pupuk Plant Catalyst, aplikasi dosis pupuk NPK 20 g/tanaman menghasilkan bobot buah yang lebih berat dibandingkan dengan dosis pupuk NPK 30 $\mathrm{g} /$ tanaman, $10 \mathrm{~g} /$ tanaman dan $0 \mathrm{~g} /$ tanaman. Namun dosis pupuk NPK $10 \mathrm{~g} /$ tanaman dan $30 \mathrm{~g} /$ tanaman menghasilkan bobot buah yang tidak berbeda nyata. Sedangkan pada perlakuan pupuk Gandasil D, aplikasi dosis pupuk NPK menghasilkan bobot buah yang tidak berbeda nyata.

Tabel 5. Pengaruh pemberian dosis pupuk NPK dan jenis pupuk pelengkap pada bobot buah per tanaman $(\mathrm{g})$

\begin{tabular}{|c|c|c|}
\hline \multirow[b]{2}{*}{$\begin{array}{c}\text { Dosis NPK } \\
\text { (g/tanaman) }\end{array}$} & \multicolumn{2}{|c|}{ Jenis Pupuk Pelengkap } \\
\hline & $\begin{array}{c}\text { Plant } \\
\text { Catalyst }\left(\mathrm{P}_{1}\right)\end{array}$ & $\begin{array}{c}\text { Gandasil D } \\
\left(\mathrm{P}_{2}\right)\end{array}$ \\
\hline $0\left(\mathrm{~N}_{0}\right)$ & $\begin{array}{c}188,00 \mathrm{~A} \\
\mathrm{c}\end{array}$ & $\begin{array}{c}284,33 \mathrm{~A} \\
\mathrm{a}\end{array}$ \\
\hline $10\left(\mathrm{~N}_{1}\right)$ & $\begin{array}{c}364,50 \mathrm{~A} \\
\mathrm{~b}\end{array}$ & $\begin{array}{c}304,83 \mathrm{~A} \\
\mathrm{a}\end{array}$ \\
\hline $20\left(\mathrm{~N}_{2}\right)$ & $\begin{array}{c}753,17 \mathrm{~A} \\
\mathrm{a}\end{array}$ & $\begin{array}{c}351,83 \mathrm{~B} \\
\mathrm{a}\end{array}$ \\
\hline $30\left(\mathrm{~N}_{3}\right)$ & $\begin{array}{c}415,33 \mathrm{~A} \\
\mathrm{~b}\end{array}$ & $\begin{array}{c}256,33 \mathrm{~B} \\
\mathrm{a}\end{array}$ \\
\hline BNT 5\% & \multicolumn{2}{|c|}{126,46} \\
\hline
\end{tabular}

Keterangan: Angka sebaris yang diikuti huruf besar yang sama dan angka sekolom yang diikuti huruf kecil yang sama menunjukkan tidak berbeda nyata pada taraf $5 \%$.

Pada perlakuan dosis pupuk NPK 0 $\mathrm{g} /$ tanaman dan $10 \mathrm{~g} /$ tanaman menghasilkan bobot buat per tanaman yang tidak berbeda nyata baik dengan aplikasi pupuk Plant Catalyst maupun pupuk Gandasil D. Namun, pada perlakuan dosis pupuk NPK 20 g/tanaman dan 30 g/tanaman, pada perlakuan dosis NPK $20 \mathrm{~g} / \mathrm{tanaman}$, aplikasi pupuk Plant Catalyst menghasilkan bobot 
buah per tanaman yang lebih berat sebesar 753,17 g dibandingkan dengan perlakuan pupuk Gandasil D yang menghasilkan bobot buah per tanaman sebesar 351,83 g dengan selisih 401,34 $\mathrm{g}$ atau sebesar 114,07\%.

Pada perlakuan dosis NPK 30 g/tanaman aplikasi Plant Catalyst menghasilkan bobot buah per tanaman yang lebih berat yaitu sebesar 415,33 g dibandingkan dengan perlakuan pupuk Gandasil D yang menghasilkan bobot buah per tanaman sebesar 256,33 g dengan selisih $159 \mathrm{~g}$ atau sebesar 62,03\%. Diagram batang pengaruh pemberian dosis pupuk NPK dan jenis pupuk pelengkap terhadap bobot buah per tanaman dapat dilihat pada Gambar 3.

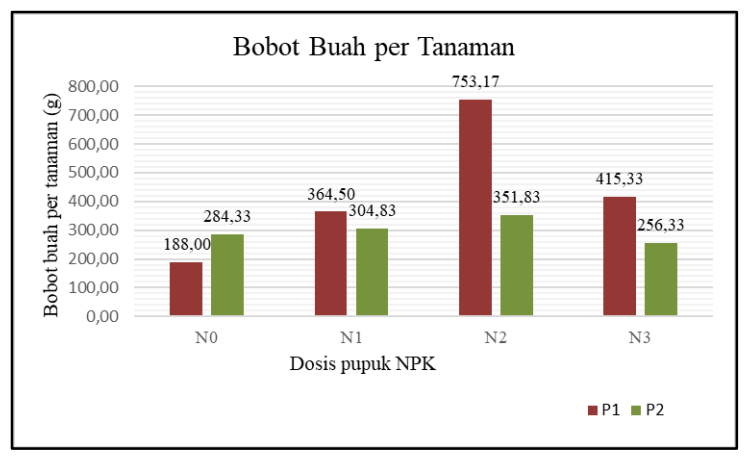

Gambar 3. Pengaruh dosis pupuk NPK dan jenis pupuk pelengkap pada bobot buah per tanaman

\section{Bobot Buah per $\mathbf{m}^{2}$}

Hasil uji lanjut BNT 5\% (Tabel 6). menunjukkan bahwa pada perlakuan pupuk Plant Catalyst, aplikasi dosis pupuk NPK 20 $\mathrm{g} /$ tanaman menghasilkan bobot buah per $\mathrm{m}^{2}$ yang lebih berat dibandingkan dengan dosis pupuk NPK $30 \mathrm{~g} /$ tanaman, $10 \mathrm{~g} /$ tanaman dan $0 \mathrm{~g} /$ tanaman. Sedangkan pada perlakuan pupuk Gandasil D aplikasi dosis pupuk NPK $20 \mathrm{~g} /$ tanaman menghasilkan bobot buah per $\mathrm{m}^{2}$ yang lebih berat dibandingkan dengan dosis pupuk NPK 30 g/tanaman, 10 $\mathrm{g} /$ tanaman dan $0 \mathrm{~g} /$ tanaman.

Pada perlakuan dosis pupuk NPK 0 $\mathrm{g} /$ tanaman dan $10 \mathrm{~g} /$ tanaman menghasilkan bobot buah per $\mathrm{m}^{2}$ yang tidak berbeda nyata baik dengan aplikasi pupuk Plant Catalyst maupun pupuk Gandasil D. Namun, pada perlakuan dosis pupuk NPK $20 \mathrm{~g} /$ tanaman dan $30 \mathrm{~g} /$ tanaman, aplikasi pupuk NPK 20 g/tanaman dan Plant Catalyst menghasilkan bobot buah per $\mathrm{m}^{2}$ yang lebih berat yaitu sebesar $3058 \mathrm{~g} / \mathrm{m}^{2}$ dibandingkan dengan perlakuan pupuk Gandasil D yang menghasilkan bobot buah per $\mathrm{m}^{2}$ sebesar $2287,33 \mathrm{~g} / \mathrm{m}^{2}$ dengan selisih $770,67 \mathrm{~g} / \mathrm{m}^{2}$ atau sebesar $33,69 \%$.

Pada perlakuan dosis NPK 30 g/tanaman aplikasi Plant Catalyst menghasilkan bobot buah per $\mathrm{m}^{2}$ yang lebih berat yaitu sebesar $2218 \mathrm{~g} / \mathrm{m}^{2}$ dibandingkan dengan perlakuan pupuk Gandasil D yang menghasilkan bobot buah per $\mathrm{m}^{2}$ sebesar $1620,67 \mathrm{~g} / \mathrm{m}^{2}$ dengan selisih $597,33 \mathrm{~g} / \mathrm{m}^{2}$ atau sebesar $36,86 \%$. Diagram batang pengaruh pemberian dosis pupuk NPK dan jenis pupuk pelengkap terhadap bobot buah per $\mathrm{m}^{2}$ dapat dilihat pada Gambar 4.

Tabel 6. Pengaruh pemberian dosis pupuk NPK dan jenis pupuk pelengkap pada bobot buah per $\mathrm{m}^{2}\left(\mathrm{~g} / \mathrm{m}^{2}\right)$

\begin{tabular}{ccc}
\hline \multirow{2}{*}{$\begin{array}{c}\text { Dosis NPK } \\
(\mathrm{g} / \text { tanaman })\end{array}$} & $\begin{array}{c}\text { Jenis Pupuk Pelengkap } \\
\text { Plant } \\
\text { Catalyst }\left(\mathrm{P}_{1}\right)\end{array}$ & $\begin{array}{c}\text { Gandasil D } \\
\left(\mathrm{P}_{2}\right)\end{array}$ \\
\hline $0\left(\mathrm{~N}_{0}\right)$ & $877,00 \mathrm{~A}$ & $1140,67 \mathrm{~A}$ \\
& $\mathrm{~d}$ & $\mathrm{c}$ \\
$10\left(\mathrm{~N}_{1}\right)$ & $1476,67 \mathrm{~A}$ & $1213,33 \mathrm{~A}$ \\
& $\mathrm{c}$ & $\mathrm{bc}$ \\
$20\left(\mathrm{~N}_{2}\right)$ & $3058,00 \mathrm{~A}$ & $2287,33 \mathrm{~B}$ \\
& $\mathrm{a}$ & $\mathrm{a}$ \\
$30\left(\mathrm{~N}_{3}\right)$ & $2218,00 \mathrm{~A}$ & $1620,67 \mathrm{~B}$ \\
$\mathrm{~b}$ & $\mathrm{~b}$ \\
\hline BNT 5\%
\end{tabular}

Keterangan: Angka sebaris yang diikuti huruf besar yang sama dan angka sekolom yang diikuti huruf kecil yang sama menunjukkan tidak berbeda nyata pada taraf $5 \%$. 


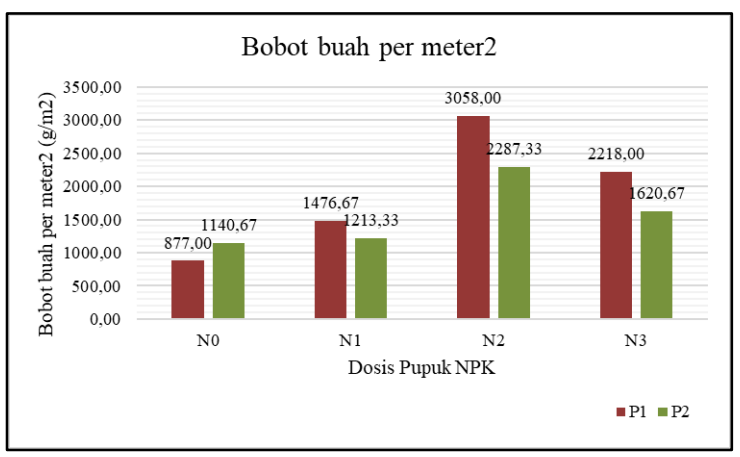

Gambar 4. Pengaruh dosis pupuk NPK dan jenis pupuk pelengkap pada bobot buah per $\mathrm{m}^{2}$

\section{Bobot Buah Rusak per Tanaman}

Hasil uji lanjut BNT 5\% (Tabel 7). menunjukkan bahwa dosis pupuk NPK 30 $\mathrm{g} /$ tanaman menghasilkan bobot buah rusak lebih berat dibandingkan dengan dosis pupuk NPK $10 \mathrm{~g} /$ tanaman dan $0 \mathrm{~g} /$ tanaman. Perlakuan dosis pupuk NPK $30 \mathrm{~g} / \mathrm{tanaman}$ menghasilkan persentase bobot buah rusak per tanaman tertinggi yaitu sebesar $16,5 \%$ dari total bobot buah pertanaman pada perlakuan dosis NPK 30 g/tanaman. Kemudian diikuti oleh perlakuan $\mathrm{N}_{0}, \mathrm{~N}_{1}$ dan $\mathrm{N}_{2}$ yang menghasilkan persentase bobot buah rusak masing - masing sebesar $15,3 \%$, $13,5 \%$ dan $10,3 \%$.

Tabel 7. Pengaruh pemberian dosis pupuk NPK dan jenis pupuk pelengkap pada bobot buah rusak per tanaman $(\mathrm{g})$

\begin{tabular}{|c|c|c|c|}
\hline \multirow{3}{*}{$\begin{array}{c}\text { Dosis NPK } \\
0 \mathrm{~g} / \operatorname{tanaman}\left(\mathrm{N}_{0}\right)\end{array}$} & \multicolumn{3}{|c|}{ Bobot Buah Rusak } \\
\hline & $(\mathrm{g}$ & & $(\%)$ \\
\hline & 42,50 & $\mathrm{c}$ & $15,3 \%$ \\
\hline $10 \mathrm{~g} / \operatorname{tanaman}\left(\mathrm{N}_{1}\right)$ & 52,08 & $\mathrm{bc}$ & $13,5 \%$ \\
\hline $20 \mathrm{~g} / \operatorname{tanaman}\left(\mathrm{N}_{2}\right)$ & 63,17 & $a b$ & $10,3 \%$ \\
\hline $30 \mathrm{~g} / \operatorname{tanaman}\left(\mathrm{N}_{3}\right)$ & 66,17 & $\mathrm{a}$ & $16,5 \%$ \\
\hline BNT 5\% & 13,79 & & \\
\hline
\end{tabular}

Keterangan: Angka yang diikuti huruf yang sama menunjukkan tidak berbeda nyata pada taraf $5 \%$.

\section{Pembahasan}

Hasil penelitian menunjukkan bahwa pupuk NPK berpengaruh nyata terhadap tinggi tanaman 19 minggu setelah tanam (mst) hal ini sejalan dengan penelitian yang dilakukan Purwanto (2020), aplikasi pupuk NPK memberikan pengaruh yang nyata terhadap tinggi tanaman 2 minggu setelah tanam (mst). Aplikasi pupuk NPK 20 g/tanaman menghasilkan tinggi tanaman tertinggi dibandingkan dengan dosis lainnya. Menurut Widyastuti dan Hendarto (2018), tinggi tanaman mengindikasi potensi munculnya cabang-cabang produksi. Tanaman semakin tinggi cenderung memiliki cabang semakin banyak. Tanaman cabai merah menghasilkan buah pada cabang sekunder, sehingga dengan mengetahui tinggi tanaman diharapkan dapat diketahui potensinya dalam menghasilkan cabang produksi.

Menurut Haryadi et al. (2015), pertambahan ukuran tanaman salah satunya yaitu tinggi tanaman merupakan proses fisiologi dimana sel melakukan pembelahan. Unsur hara $\mathrm{N}$ berperan dalam pembentukan sel, jaringan dan organ tanaman. Unsur hara $\mathrm{N}$ dibutuhkan tanaman dalam pertumbuhan vegetatif tanaman. Menurut Rajiman (2020), Nitrogen berperan dalam merangsang pertumbuhan vegetatif, penyusun bahan klorofil, lemak dan protein, serta meningkatkan pertumbuhan tanaman. Penambahan pupuk yang mengandung $\mathrm{N}$ salah satunya yaitu pupuk NPK akan mempengaruhi kadar $\mathrm{N}$ total dan membantu mengaktifkan sel - sel tanaman dan mempertahankan jalannya proses fotosintesis yang pada akhirnya pertumbuhan tanaman dapat dipengaruhi.

Pemberian dosis pupuk NPK 30 g/tanaman cenderung menyebabkan pertumbuhan dan produksi yang menurun serta terjadi peningkatan jumlah buah rusak serta bobot buah rusak per tanaman yang lebih tinggi. Hal ini diduga karena terjadinya ketidakseimbangan hara di dalam tanah maupun tanaman yang menyebabkan beberapa unsur hara berada dalam konsentrasi yang lebih tinggi namun beberapa unsur hara lainnya mengalami defisiensi sehingga pertumbuhan tanaman 
menjadi terhambat. Kelebihan unsur hara N dapat menyebabkan tanaman menghasilkan daun yang lebih banyak, fase vegetatif tanaman menjadi lebih panjang sehingga tanaman lambat dalam menghasilkan bunga dan buah, batang tanaman dan buah menjadi lebih renyah sehingga disenangi oleh hama (Rajiman, 2020). Menurut Lingga dan Marsono (2008), pemberian pupuk harus tepat sesuai dengan konsentrasi yang dianjurkan karena pemberian pupuk yang berlebihan akan menyebabkan tanaman mengalami keracunan sehingga hasil menurun.

Jenis pupuk pelengkap Plant Catalyst menghasilkan produksi yang tertinggi dibandingkan dengan pupuk Gandasil D terlihat pada variabel jumlah buah per tanaman, bobot buah per tanaman dan bobot buah per $\mathrm{m}^{2}$. Hasil penelitian Purwanto (2020), menunjukkan bahwa pemberian konsentrasi pupuk Plant Catalyst dengan konsentrasi $1 \mathrm{~g} / \mathrm{l}$ dan 1,5 $\mathrm{g} / \mathrm{l}$ cenderung menghasilkan jumlah buah per tanaman yang lebih banyak yaitu 29,75 buah dan bobot buah per tanaman yang lebih tinggi yaitu 73,25 dan 71,75 g/tanaman dibandingkan tanpa aplikasi pupuk Plant Catalyst. Hal ini diduga karena pupuk Plant Catalyst memiliki kandungan unsur hara yang lebih lengkap dibandingkan dengan pupuk Gandasil D sehingga terjadi keseimbangan hara di dalam tanaman yang dapat memberikan hasil yang tinggi. Selain itu, kandungan unsur $\mathrm{N}$ yang tidak terlalu tinggi pada Plant Catalyst memberikan hasil yang tinggi karena dalam pertumbuhan fase generatif, tanaman tidak memerlukan unsur hara $\mathrm{N}$ yang tinggi sehingga kebutuhan unsur $\mathrm{N}$ telah terpenuhi melalui pemupukan NPK. Pupuk Plant Catalyst mengandung unsur hara lengkap yang dibutuhkan untuk pertumbuhan dan produksi tanaman meliputi unsur hara makro dan unsur hara mikro. Unsur hara makro yang terkandung adalah (N, P, K, Ca, Mg, S, C), sedangkan unsur hara mikro yang terkandung adalah $(\mathrm{Fe}, \mathrm{Cl}$, $\mathrm{Mn}, \mathrm{Cu}, \mathrm{Co}, \mathrm{Zn}, \mathrm{B}, \mathrm{Na}, \mathrm{Al}$ dan $\mathrm{Mo}$ ). Sebagian besar unsur hara mikro tersebut berperan dalam komponen penyusun enzim yang berperan sebagai katalisator dalam metabolisme tanaman.

Pupuk Gandasil D menghasilkan pertumbuhan vegetatif tanaman lebih tinggi dibandingkan dengan Plant Catalyst yang dapat dilihat pada variabel tinggi tanaman. Hasil penelitian Maulani (2018), menunjukkan bahwa aplikasi pupuk Gandasil D berpengaruh nyata dalam meningkatkan tinggi tanaman cabai umur 28 dan 42 HST dibandingkan tanpa pemberian pupuk Gandasil D. Konsentrasi pupuk Gandasil D 3,0 g/l mampu menghasilkan tinggi tanaman tertinggi pada 28 dan 42 HST yaitu 25,06 dan 42,81 cm. Hal ini diduga karena kandungan unsur hara makro khususnya unsur $\mathrm{N}$ yang terkandung di dalam pupuk gandasil $\mathrm{D}$ lebih tinggi dibandingkan dengan pupuk Plant Catalyst sehingga pertumbuhan vegetatif tanaman lebih cepat. Pada masa pertumbuhan unsur hara nitrogen merupakan bagian utama dari pembentuk asam amino dan asam nukleat. Dalam pertumbuhan vegetatif tanaman terutama tinggi tanaman unsur hara nitrogen dibutuhkan tanaman dalam jumlah yang relatif lebih banyak dibandingkan dengan unsur hara lainnya. Nitrogen yang terdapat pada pupuk gandasil D, dapat membantu mempercepat pertumbuhan vegetatif pada tanaman, memperbaiki kualitas daun dan akar. Nitrogen juga berperan sebagai penyusun protoplasma, sehingga mengakibatkan dinding sel dapat bertambah (Qibtyah, 2015).

Aplikasi pupuk Gandasil D menghasilkan pertumbuhan vegetatif yang lebih baik dibandingkan aplikasi pupuk Plant Catalyst, namun Gandasil D menghasilkan produksi yang lebih rendah dibandingkan dengan Plant Catalyst hal ini dikarenakan pada aplikasi pupuk Gandasil $\mathrm{D}$, bunga yang terbentuk mengalami kerontokan serta buah kecil yang terserang hama lalat buah dan ulat sehingga mengalami kerusakan dan tidak berkembang menjadi buah besar. Hal ini diduga karena 
kandungan Nitrogen yang terdapat di dalam pupuk Gandasil D cukup tinggi.

Menurut Sumarni et al. (2014), Nitrogen yang tinggi dapat menyebabkan ketersediaan nutrisi yang ideal dan jaringan daun yang lemah sehingga disenangi hama dan memudahkan cendawan menginfeksi tanaman. Sedangkan pada aplikasi Plant Catalyst intensitas serangan hama lebih rendah menurut PT Centra Nusa Insan Cemerlang (2014), aplikasi Plant Catalyst dapat menaikkan $\mathrm{pH}$ atau menetralkan asam tanah serta mematikan cendawan penyakit dan bakteri apabila aplikasi mengenai tanah atau lubang tanam, hal ini dikarenakan Plant Catalyst mengandung kation basa diantaranya $\mathrm{Ca}, \mathrm{Mg}, \mathrm{K}$ dan $\mathrm{Na}$ yang dapat meningkatkan $\mathrm{pH}$ dan Kapasitas Tukar Kation. Kandungan Ca pada Plant Catalyst dapat memperkuat dinding sel dalam jaringan tanaman. Dinding sel yang lebih kuat dan sehat akan mengurangi serangan hama dan penyakit sehingga kualitas hasil panen lebih baik dan tidak mudah busuk. Menurut Ariyadni dan Nur (2019), kalsium mampu meningkatkan kualitas dan hasil buah cabai karena kalsium merupakan unsur yang berperan dalam meningkatkan kekuatan dinding buah, mengurangi gangguan fisiologis serta memperpanjang umur simpan buah cabai.

Interaksi dosis pupuk NPK 20 g/tanaman dengan pupuk Plant Catalyst menghasilkan produksi yang tertinggi hal ini ditunjukkan oleh variabel jumlah buah per tanaman, bobot buah per tanaman dan bobot buah per $\mathrm{m}^{2}$. Hal ini diduga karena dosis NPK 20 g/tanaman optimal dalam mencukupi kebutuhan unsur hara N, P dan K yang diperlukan tanaman. Selain itu, kebutuhan unsur hara mikro tanaman terpenuhi melalui pemupukan dengan pupuk Plant Catalyst. Interaksi pupuk NPK dan jenis pupuk pelengkap diduga karena pemberian salah satu jenis pupuk yaitu pupuk NPK saja belum mampu memenuhi kebutuhan unsur hara secara keseluruhan karena kandungan utama dalam pupuk NPK
Mutiara yaitu $16 \% \mathrm{~N}, 16 \% \mathrm{P}_{2} \mathrm{O}_{5}$ dan $16 \%$ $\mathrm{K}_{2} \mathrm{O}$.

Menurut Handayanto et al. (2017), Tanaman memerlukan paling sedikit 16 unsur hara essensial untuk pertumbuhan dan menuntaskan siklus hidupnya. Defisiensi unsur hara essensial dapat menyebabkan tanaman tidak dapat menyelesaikan stadium pertumbuhan terutama stadium vegetatif dan generatif. Defisiensi bersifat spesifik pada unsur hara essensial hanya dapat diperbaiki dengan penambahan unsur tersebut dan tidak dapat digantikan dengan unsur lainnya karena terlibat langsung dalam metabolisme dan diperlukan untuk aktivitas enzim. Pertumbuhan tanaman dibatasi oleh satu faktor yang berada dalam jumlah minimum dan pertumbuhan dapat meningkat jika faktor minimum ditingkatkan. Interaksi pemberian dosis pupuk NPK dan jenis pupuk pelengkap diduga karena unsur hara yang terkandung dalam pupuk pelengkap mampu melengkapi kebutuhan unsur hara yang tidak disediakan oleh pupuk NPK. Menurut Purwanto (2020), dua faktor dikatakan berinteraksi apabila pengaruh suatu faktor perlakuan berubah pada saat faktor perlakuan lainnya berubah.

Secara umum hasil penelitian menunjukkan bahwa interaksi perlakuan dosis pupuk NPK 100\% atau $20 \mathrm{~g} /$ tanaman dengan pupuk Plant Catalyst menghasilkan bobot buah per tanaman yang lebih tinggi dibandingkan interaksi perlakuan lainnya yaitu sebesar 753,17 g/tanaman sehingga produktivitas cabai yang dihasilkan setara dengan 15,06 ton/ha pada populasi 20.000 tanaman/ha. Produktivitas tersebut sudah melebihi produktivitas cabai merah nasional yang dapat mencapai $\pm 8,6$ ton/ha dan melebihi produktivitas cabai di Provinsi Lampung sebesar 6,23 ton/ha.

Pada interaksi perlakuan dosis NPK 30 g/tanaman dengan pupuk Plant Catalyst menghasilkan bobot buah per tanaman sebesar 415,33 g/tanaman sehingga produktivitas cabai yang dihasilkan mencapai 8,3 ton/ha. Pemupukan NPK dengan dosis yang lebih tinggi (30 
g/tanaman) mengakibatkan produksi menurun dibandingkan dengan perlakuan 20 g/tanaman. Hal ini diduga karena frekuensi pemberian pupuk NPK pada penelitian ini dilakukan sebanyak 3 kali dengan pembagian $50 \%$, 25\% dan $25 \%$ sehingga konsentrasinya dalam tanah berlebih. Namun, aplikasi dosis pupuk NPK 30 g/tanaman dapat digunakan apabila frekuensi pemupukan diperpanjang dengan pemberian sedikit demi sedikit sesuai dengan umur produktif cabai yang dapat mencapai $6-7$ bulan sehingga pupuk yang diberikan menjadi tersedia bagi tanaman dan dapat memperpanjang umur produktif cabai sehingga produksi tanaman akan meningkat seiring dengan penambahan dosis pupuk NPK sampai batas tertentu.

\section{KESIMPULAN}

Dari hasil penelitian ini dapat disimpulkan bahwa:

(1) Pemberian dosis pupuk NPK 20 $\mathrm{g} /$ tanaman memberikan hasil terbaik pada tinggi tanaman 19 minggu setelah tanam (mst), jumlah buah per tanaman, bobot buah per tanaman dan bobot buah per $\mathrm{m}^{2}$.

(2) Pemberian jenis pupuk pelengkap Plant Catalyst memberikan hasil terbaik pada jumlah buah per tanaman, bobot buah per tanaman dan bobot buah per $\mathrm{m}^{2}$, namun Aplikasi pupuk Gandasil D memberikan hasil terbaik pada tinggi tanaman 19 minggu setelah tanam.

(3) Pemberian dosis pupuk NPK dipengaruhi oleh jenis pupuk pelengkap. Interaksi dosis pupuk NPK $20 \mathrm{~g} /$ tanaman dengan pupuk Plant Catalyst menghasilkan produksi yang tertinggi yaitu 753,17 $\mathrm{g} /$ tanaman $(15,06$ ton/ha pada populasi 20.000 tanaman) lebih tinggi $114,07 \%$ dibandingkan dengan perlakuan pupuk Gandasil D yang hanya menghasilkan bobot buah per tanaman 351,83 $\mathrm{g} /$ tanaman $(8,3$ ton/ha). Interaksi dosis pupuk NPK $20 \mathrm{~g} /$ tanaman dan pupuk Gandasil D menghasilkan tinggi tanaman tertinggi yaitu $95,58 \mathrm{~cm}$ lebih tinggi $8,21 \%$ dibandingkan dengan Plant Catalyst yang menghasilkan tinggi tanaman $88,33 \mathrm{~cm}$.

\section{DAFTAR PUSTAKA}

Agriflo, T. P. 2012. Cabai, Prospek Bisnis dan Teknologi Mancanegara. Agriflo (Penebar Swadaya Group). Jakarta. 205 hlm.

Ariyadni, D. R., dan N. E. Suminarti. 2019. Pengaruh Pupuk Kalsium dan Giberelin pada Pertumbuhan, Hasil dan Kualitas Cabai Besar (Capsicum annuum). J Produksi Tanaman, 7 (12). 2262 - 2271.

Handayanto, E., N. Muddarisna., dan A. Fiqri. 2017. Pengelolaan Kesuburan Tanah. UB Press. Malang. 198 hlm.

Hartatik, W., dan L. R. Widowati. 2015. Pengaruh Pupuk Majemuk NPKS dan NPK terhadap Pertumbuhan dan Hasil Padi Sawah pada Inceptisol. Penelitian Tanaman Pangan, 34 (3). 175 - 185.

Haryadi, D., H. Yetti., dan S. Yoseva. 2015. Pengaruh Pemberian Beberapa Jenis Pupuk Terhadap Pertumbuhan dan Produksi Tanaman Kailan (Brassica alboglabra L.). Jom Faperta, 2 (2).

Kaya, E. 2013. Pengaruh Kompos Jerami dan Pupuk NPK Terhadap N-Tersedia Tanah, Serapan N, Pertumbuhan dan Hasil Padi Sawah (Oryza sativa L.). J Agrologia, 2 (1). $113-122$.

Kementerian Pertanian Republik Indonesia. 2019. Data Produksi, Luas Panen dan Produktivitas Cabai Besar Menurut Provinsi 2015-2019. https://www. pertanian.go.id/home/?show=page\&act= view\&id=61. Diakses pada 23 Agustus 2020.

Lingga, P. dan Marsono. 2008. Petunjuk Penggunaan Pupuk. Penebar Swadaya. Jakarta. $150 \mathrm{hlm}$.

Maulani, N. W. 2018. Pengaruh Berbagai Konsentrasi Pupuk Daun Terhadap Pertumbuhan dan Hasil Cabai Merah Keriting (Capsicum annuum L.) Kultivar Andalas. J Agrorektan. 5 (1). 44 - 58. 
Novizan. 2007. Petunjuk Pemupukan Pemupukan Yang Efektif. Agromedia Pustaka. Jakarta. 114 hlm.

PT. Centranusa Insan Cemerlang. 2014. Pupuk Pelengkap Plant Catalyst 2006. Leaflet. Tidak dipublikasikan.

Purnomo, J. 2013. Pemupukan Berimbang pada Tanaman Cabai pada Tanah Typic Hapludands di Cikembang, Sukabumi. Prosiding Seminar Nasional Peningkatan Produktivitas Sayuran Dataran Tinggi 218 -228 .

Purwanto, D. 2020. Pengaruh Pupuk NPK Mutiara dan Pupuk Plant Catalyst terhadap Pertumbuhan dan Hasil Tanaman Cabai Merah Keriting (Capsicum annuum L.) Varietas Lado F1. J Agrifor, 19 (1): 123 - 134.

Qibtyah, M. 2015. Pengaruh Pengunaan Konsentrasi Pupuk Daun Gandasil D dan Dosis Pupuk Guano Terhadap Pertumbuhan dan Produksi Cabai Merah (Capsicum annuum L.). J Saintis, 7 (2): $109-122$.
Rajiman. 2020. Pengantar Pemupukan. Deepublish. Yogyakarta. $177 \mathrm{hlm}$.

Sumarni, N., W. Setiawati., dan A. Hudayya. 2014. Pengelolaan Hara dan Tanaman untuk Mendukung Usahatani Cabai Merah Menggunakan Input Luar Rendah di Dataran Tinggi. J. Hort. 24 (2). 141 153.

Syukur, M., S. Sujiprihati, dan A. Siregar. 2010. Pendugaan parameter genetik beberapa karakter agronomi cabai F4 dan evaluasi daya hasilnya menggunakan rancangan pembesaran (Augmented Design). Jurnal Agrotropika, 15(1): 9-16.

Widyastuti, R. A. D., dan K. Hendarto. 2018. Uji Efektifitas Penggunaan Pupuk NPK dan Pupuk Kandang Terhadap Pertumbuhan Cabai Merah. Agrica Ekstensia, 12 (1): 20 $-26$. 